\title{
SAEVAE MEMOREM IUNONIS OB IRAM JUNO, VEII, AND AUGUSTUS
}

\begin{abstract}
Arma virumque cano, Troiae qui primus ab oris Italiam, fato profugus, Laviniaque venit litora, multum ille et terris iactatus et alto vi superum saevae memorem Iunonis ob iram.
\end{abstract}

Aen. I 1-4

\begin{abstract}
Summary: A driving force in Vergil's Aeneid is the hostility of Juno to the Trojans as they approach, and finally arrive in Italy. The epic in some ways mirrors the opposition encountered by Augustus as the new ruler of Rome. Juno's opposition to the Trojans has its origin not only in Greek mythology, but in the history of the local peoples of Italy with whom early Romans had to contend. From the outset of the poem she becomes the personification of these opposing forces. Once the Trojans finally reach mainland Italy, she sets in motion a long war, although the one depicted in the Aeneid was not as long as the real wars Romans waged with the Latin League and with the many of the tribes of Italy, including the Veii. The reality of the wars Rome had to contend with are here compared to the relatively brief one depicted in the Aeneid, and the pacification of Juno reflects the merging of the different peoples of Rome with their subjugator.
\end{abstract}

Key words: Juno, saeva, MARS acrostic, Etruscan Uni, evocatio, Veii, Fidenae, Aventinus, Gabii, Praeneste, Tibur, Tanit, Saturnia, Apollo, Cumae and Hera, asylum, Athena, Aeneas, Anchises' prophecy

An important part of Augustan Myth is found in Vergil's depiction of Juno, who is named in the opening lines of the epic and is a persistent presence throughout the poem. This depiction is significant from the opening lines of the Aeneid, ${ }^{1}$ and resurfaces in

${ }^{1}$ The classical works cited are: Augustus, Res Gestae: http://http://www.thelatinlibrary.com/ resgestae; Livy, Ab Urbe Condita. http://www.thelatinlibrary.com/livy/; AUSTIN, R. G.: P. Vergili Maronis Aeneidos: Liber Sextus. Oxford at the Clarendon Press 1977; P. Vergili Maronis Opera. Ed. R. A. B. MYNORS. Oxford at the Clarendon Press1969. See my translation of the entire book, Johnston, P. A. 2012. The Aeneid of Vergil. Translated by Patricia A. Johnston. Oklahoma University Press: Norman, OK, and my 
a number of ways throughout the poem. I first raised this issue in 1981, in an article examining the outbreak of the Latin/Trojan war in Aeneid VII and the acronym MARS (601-604), which introduces Juno pushing open the gates of War. ${ }^{2}$ I again raised this issue in 1998, when I examined the displacement of Juno at Cumae, the original goddess and source of prophecy at that site, by Apollo. ${ }^{3}$ It becomes particularly strong in the later books - it is implied in Anchises' prophecy in Book VI, and becomes quite explicit in Book VII, where her ties with the local Italic tribes tends to reinforce her importance in Italy before the arrival of the Trojans. Livy's account of the long struggle between Rome and Veii, the Etruscan city nearest to the borders of Latium, whose fall was marked by the evocation ${ }^{4}$ of Juno's statue and its transposition to Rome, are consistent with the efforts of Augustus, functioning, in Galinsky's words, as the "civilis princeps", the one who unites the disparate parts of the Roman state.

Scholars, and even recent handbooks on the Aeneid, have tended to dismiss Juno as merely a malcontented, Homeric, Hera. Others have interpreted her as Ennius' divine protagonist against Rome in the Hannibalic war (based on what are assumed to be Silius Italicus' borrowings from Ennius' hypothetical text). ${ }^{5}$ More recent commentators have argued, ${ }^{6}$ however, that Vergil's Juno was part of a very long-term construction in the myth of Augustus. Even Juno's so-called "sanctuary", which in Aen. II 760-767, Vergil calls her asylum, her "sanctuary" was a Vergilian construct, apparently replacing the actual temple of Athena at Troy. ${ }^{7}$ Galinsky argues that much of this myth-making was done by Augustus himself, who associated himself with many deities, not just Apollo (Apollo, in Galinsky's view, was there, "mostly for poets"). ${ }^{8}$

In the first six books of the Aeneid, it is said repeatedly that, despite Juno's opposition, the Trojans are fated to succeed, and that their new homeland will be in

commentary (2013) on Book 6, Vergil Aeneid Book 6, in The Focus Vergil Aeneid Commentaries. Newburyport MA: Focus Publishing.

${ }^{2}$ Johnston, P. A.: The Storm in Aeneid VII. Vergilius 27 (1981) 23-30; cf. Fowler, D. P.: An Acrostic in Vergil. CQ 33 (1983) 298; and BARCHIESI, A.: Martial Arts. Mars Ultor in the Forum Augustum: A Verbal Monument with a Vengeance. In Herbert-Brown, G.: Ovid's Fasti. Oxford University Press 2002, 1-22.

${ }^{3}$ JohnSTON, P. A.: Juno's Anger and the Sibyl at Cumae. Vergilius 44 (1998) 13-23.

${ }^{4}$ Recorded examples of evocations include the transfer of Juno Regina /Etruscan Uni from Veii in 396 BCE, and the ritual involving Tanit (Juno Caelestis), which was performed after Scipio Aemilianus' defeat of Carthage in 146 BC (Livy 2. 47-48).

${ }^{5}$ FeENEY, D. C.: The Reconciliations of Juno. CQ N.S. 34.1 (1984) 179-194, here n. 4, $179 \mathrm{ff}$. Cf. NORDEN, E.: Ennius und Vergilius:Kriegsbilder aus Roms grosser Zeit. Leipzig 1915.

${ }^{6}$ ReBEgGiani, S.: Words of Marble: Vergil's temple of Juno in Aeneid 1 and the Construction of the Augustan Myth. In LABATE, M. - Rosati, G.: La costruzione del mito augusteo. Heidelberg 2013, 149-168. REBEGGIANI 149 identifies it as her 'Temple' at Troy.

${ }^{7}$ GALINSKY, K.: La costruzione del mito augusteo. Some construction elements. In LABATE-ROSATI (n. 6) 29-39. Galinsky's earlier works on the topic include Augustan Culture. Princeton 1996; (ed.) The Cambridge Companion to the Age of Augustus. Cambridge 2005; Augustus. Introduction to the Life of an Emperor Cambridge 2012.

${ }^{8}$ GALINSKY: La costruzione (n. 7) 41. Some scholars have tended to focus on Ennius' reported account of Juno's support of Hannibal in the Punic Wars, and her purported conversion there to support the Romans $(293 \mathrm{~W}=292 \mathrm{~V})$. The purpose of this paper is to refocus that argument, and instead to examine Juno as a deity who already occupied Italy at the time of the Trojans' arrival. Cf. FEENEY (n. 5) 179-194 and references there. 
Italy, where they will establish the new Roman race which will eventually rule the world. The last six books show their struggle to gain a foothold in Italy after they have landed. Vergil focuses, from the outset, on Juno's opposition to them - beginning with the saevae memorem Iunonis ob iram, Aen. I 4. A few lines later, Vergil asks what great wrong had been done to the queen of the gods, a wrong so great that it motivated her continuous attacks on the Trojans, and he names the traditional, Greek reasoning (Ganymede, Paris's decision, and of the course the conflict at Troy, but as the story unfolds it becomes increasingly clear that the Trojans are undermining Juno's power base - not merely Samos, but also Carthage, as well as Italy itself: Since Juno already had a presence in Italy before the Trojans arrived, we must take into consideration her early role in Italy, especially in view of the attempts by Augustus to reconcile the long struggles the Romans and their predecessors had encountered in Italy, which Livy traces back to Romulus himself. ${ }^{9}$

In the case of Juno, the long struggle between Rome and Veii is a good example of the background to this discussion, as the fall of this Etruscan city, on the borders of Latium, was marked by the evocation ${ }^{10}$ of their goddess, Uni, and her transposition to Rome. Recorded evocations include the transfer of Juno Regina/Etruscan Uni from Veii in 396 BCE and the same ritual involving Tanit (= Juno Caelestis) was performed by Scipio Aemilianus in 146 BCE after the defeat of Carthage. The third recorded occurrence was the dedication of a temple to an unnamed deity at Issura Vetus in 75 BCE in Cilicia. ${ }^{11}$ Hence we have evidence that Juno's hostility to the Trojans may also be viewed more in the context of the goddess's desire to protect her homelands - which, as I have said, would include Italy as well as Carthage - than by any unhappiness over

${ }^{9}$ Livy, Ab Urbe Condita. http://www.thelatinlibrary.com/livy/.

${ }^{10}$ Recorded examples of evocations include the transfer of Juno Regina /Etruscan Uni from Veii in 396 BCE, and the ritual involving Tanit (Juno Caelestis) performed by in 146 BCE, after the defeat of Carthage by Scipio Aemilianus. (Elizabeth Rawson expresses doubts as to whether the evocatio of 146 BCE occurred as such; see RAwSON, E.: Scipio, Laelius, Furius and the Ancestral Religion. JRS 63 [1973] 161-174). Some scholars think that Vortumnus (Etruscan Voltumna) was brought by evocation to Rome in 264 BCE as a result of M. Fulvius Flaccus' defeat of the Volsinii.

${ }^{11}$ To some degree the struggle reflect those between the Latin League, the Etruscans, the Volsci, etc., as reflected in the predictions by Anchises in Book VI (as he anticipates their all becoming one people) and in the presences of their representatives in Book VII and later. See also MUELLER, H.-F.: Vita, Pudicitia, Libertas: Juno, Gender, and Religious Politics in Valerius Maximus. TAPA 128 (1998) 221-263, here 223-224. Mueller writes that Valerius Maximus, writing Facta et Dicta Memorabilia, under Tiberius, to whom he dedicated his work, "divides his exempla into two categories: Roman and foreign, mostly Greek... There Roman Juno appears as a stern goddess, somewhat prone to anger. She is animated by the power of chastity (6. 1. init.), sets an austere example of earlier manners (2. 1. 2), takes offense at the presence of a beautiful male actor in her husband's chariot (1.1.16), takes vengeance on Q. Fulvius Flaccus for stealing marble from her temple (1. 1.20), receives a temple on the spot where M. Manlius Capitolinus' house once stood (6. 3. 1), but, in spite of all provocations, comes willingly to Rome from Veii (1. 8. 3). Foreign Juno's temple is the site of a miracle; winds cannot move ashes there (1. 8. ext. 18); she forgives the sacrilege of Masinissa (1. 1. ext. 2), and she takes the lives of Cleobis and Biton (5. 4. ext. 4). The rubrics under which Juno appears are revealing also: she is harsh, she is concerned with proper behavior, and she has power to intervene in the affairs of this world: de neglecta religione (1. 1. 16; 1. 1. 20, 1. 1. ext. 2); de miraculis (1. 8. 3, 1. 8. ext. 18); de seueritate (6. 3. 1); de pudicitia (6. 1. init.); de institutis antiquis (2. 1. 2); de pietate erga parentes et fratres et patriam (5. 4. ext. 4); and de parentibus, qui obitum liberorumforti animo tulerunt (5. 10. 2)." 
past struggles in the Greek world. After Vergil questions the source of Juno's great anger, in the prologue to book one (Aen. I 9-10), he proceeds to indicate, in effect, that her real concern has not so much to do with things Greek, but rather with Carthage, a city dear to Juno, which was destined to be destroyed by the Romans - and, of course, happened, in the Punic Wars. ${ }^{12}$

In Aeneid 7, when war is declared between the Latins and the Trojans, it is not Mars but Juno who sets the conflict in motion: Nec minus interea extremam Saturnia bello/imponit regina manum (VII 572-573): "No less than the Saturnian queen imposes the final 'hand'/say" on the pending struggle", and she "pushes open the gates of war". The acrostic that introduces this action, as Barchiesi observes, ${ }^{13}$ is the only time that Mars, the god of war is present in the entire Aeneid - it is Juno, daughter of Saturn, who is the main deity of war in this epic. Note that the gates open with the acrostic MARS (VII 601-604), and the opening concludes with Belli (VII 617):

Mos erat Hesperio in Latio, quem protinus urbes

Albanae coluere sacrum, nunc maxima rerum

Roma colit, cum prima movent in proelia Martem, sive Getis inferre manu lacrimabile bellum Aen. VII 601-604 [...] impulit ipsa manu portas, et cardine verso Belli ferratos rumpit Saturnia postis. [...] Aen. VII 616-617

It is perhaps worth noting here that, according to Livy, Mezentius, the king of the Etruscans, and the first name on the list of Latin opponents (VII 648), whom Vergil represents as contemptor deorum, actually outlived Aeneas and the war with the Trojans, and even made peace with them. ${ }^{14}$ Vergil presents Mezentius' son, Lausus, in very positive terms, in contrast with, and ultimately as a victim of, his father's wickedness (we are told he deserves "not to have Mezentius as his father", dignus ... cui pater haud Mezentius esset, VII 654). Mezentius and Lausus lead troops from Caere (= Cerveteri, Lat. Agyllina), one of the larger cities of Southern Etruria, an area still known in our time for its Etruscan necropolises and archeological treasures.

Next in the list, after Mezentius and his son, is Aventinus, who is descended from Hercules. Vergil here briefly mentions Hercules' defeat of Geryon, whose cattle he washed in the Tiber (Tyrrheno... flumine, VII 663-664). It appears that, in addition to this connection to Hercules, Vergil may have intended a reference to Juno in the name of Aventinus, since her statue was placed on the Aventine hill, in a temple to Veientine Juno, after the Romans finally conquered Veii.

The twin brothers Catillus and brave Coras (VII 672), although not Etruscan, may also suggest a connection to Juno, since in line VII 670 Vergil calls them "Argive

\footnotetext{
${ }^{12}$ Ennius Ann. 291 V, followed by Servius ad Aen. 1. 281, indicated that Juno was finally reconciled to the Trojans after the Second Punic War. Cf. FEENEY (n. 5) 179 and notes 2 and 4 for other sources.

${ }^{13}$ BARCHIESI (n. 3).

${ }^{14}$ In the traditional myth that predates the Aeneid, Mezentius actually outlived Aeneas. Since Vergil's benefactor Maecenas was a native Etruscan, Virgil portrayed Mezentius as an evil tyrant,in contrast to the other "good Etruscans" who fight alongside Aeneas.
} 
youths from Tibur" (Argiva iuventus), reminding us of Vergil's various references in the early books to Juno's ties to Argos and her "dear Argives" (pro caris ... Argis, I 24)" The description of Caeculus (VII 680), founder of Etruscan Praeneste, and the reference to the Gabii (VII 682), again reminds us of Juno because of the statement that he and his legions inhabit Praeneste and the fields of Gabinian Juno (quique altum Praeneste viri quique arva Gabinae / Iunonis, VII 681-682). It is interesting to note that in VII 612 the guardian (custos) of the Gates of War is said to wear a "Gabine belt" (cinctuque Gabino). ${ }^{15}$

The entire list of tribes in this section reflects many other of the native peoples with whom Rome waged wars during its early history, from the sixth and fifth centuries BCE down to the Social Wars of the first century BCE. Rome's first major war against an organized state was fought by Romulus, the founder of Rome, with Fidenae (437-426 BCE). ${ }^{16}$ This town was located just up the river Tiber from Rome. In the underworld (Aen. VI), Aeneas' father Anchises names, among the native peoples/towns which will become part of Rome, Fidenae, as well as Nomentum (listed in VII 712 as one of the Sabine cities opposing the Trojans) and Gabii.

\section{Procas ... et Capys et Numitor et qui te nomine reddet \\ Silvius Aeneas ... qui iuvenes! [...] hi tibi Nomentum et Gabios urbemque Fidenam [...]} Aen. VI 771-773

Procas ... and Capys and Numitor and Silvius Aeneas, who will share your name ... What men! [...]

These will found Nomentum and Gabii and the city Fidenae.

After Fidenae was conquered, its land was annexed to Roman territory. Rome then fought a long and difficult series of wars - from 483 to 396 BCE, (about 90 years) against Veii alone. Veii, located near Fidenae, was a major Etruscan town, was located about ten miles northwest of Rome, in the Alban Hills near the Appian Way; ${ }^{17}$ it was a constant enemy of the Romans. In the fifth century BCE, Romans waged at least three major wars with this town (some annalists list up to fourteen wars). Cornell says that

${ }^{15}$ Gabii was an ancient city about 12 miles from Rome (now known as Castiglione).

${ }^{16}$ According to Livy, Fidenae allied itself to Veii in the fifth century, which resulted in its destruction when Rome attacked its Etruscan rival (Livy 4. 22 and 4. 35). The place was abandoned (cf. Hor. Ep. 1. 11. 8) and only used to quarry tufa (Vitruvius, De architectura 2. 7. 1), but it could be used for public gatherings. During one of these, in the year $27 \mathrm{CE}$, a wooden amphitheater collapsed; according to Suetonius, no less than twenty thousand people were killed (Suet. Tib. 40). The site was also used by Hannibal during his war against Rome (Livy 26. 10).

${ }^{17}$ Veii, modern Isola Farnese, is an ancient Etruscan town located about 10 miles $(16 \mathrm{~km})$ northwest of Rome. Veii was a center for the fabrication of terra-cotta sculptures in Etruria in the 6th century BCE. According to Pliny the Elder, Vulca of Veii made the terra-cotta statues for the Temple of Jupiter on the Roman Capitol in the late 6th century BCE. The town had hegemony over Rome in the 7 th and 6 th centuries, but wars with Rome ended in the destruction of Veii (396 BCE). Its destruction was not total, however, and the Romans later reconstructed the city. Under Augustus, in 2 BCE, it was made a municipium (a community that exercised partial rights of Roman citizenship), and up to the 3rd century CE it continued as a religious center. 
their main point of contention apparently concerned access to the routes traveling from north to south and vice versa, which had to go either through the territory of Rome or of Veii. According to Cornell, these wars were "organized conflicts between developed states". ${ }^{18}$ In the first Veientine War (483-474), Veii was successful. The second Veientine War (437-435) broke out when the tyrant of Veii, Tolumnius, had four of the Roman ambassadors killed. The Romans were eventually victorious in this second conflict, but their leaders, Quintus Fabius and his brother Manlius Fabius, were both killed in the fighting. ${ }^{19}$ Twenty years later, the Romans launched the third Veientine War (406-396) with a full-scale attack on the city itself. The siege that followed was said to have lasted ten years, and ended when the Roman Dictator M. Furius Camillus captured the city.

Later Roman historians compare this final, ten-year war (406-396) to what Cornell calls the "mythical" Trojan War waged by the Greeks. ${ }^{20}$ After the fall of Veii in 396, it was incorporated into the Roman territory, and, after its conquest, Veii's tutelary goddess, Juno Regina, was solemnly summoned to Rome, by evocatio. The city's territory was annexed, increasing Roman territory by 84 percent and forming four new rustic tribes.

According to Livy, the soldiers assigned to remove the statue from Veii "shrank at first from what seemed the sacrilege of laying hands upon an image... Suddenly one of them said: 'Juno, do you want to go to Rome (visne Romam ire, Iuno?)?' Whether the question was divinely inspired," 〈says Livy $\rangle$, "or merely a young man's joke, who knows? but his companions all declared that the statue nodded its head in reply" (Livy 5. 22, trans. de Selincourt).

Evocatio, a "calling out", was a ritual conducted in a military setting either as a threat during a siege of a city, or as the result of surrender, and was aimed at turning away the favor of a name deity from the opposing city to the Roman side, usually with the promise of a better-endowed cult or a more lavish temple. As a tactic of psychological warfare, evocatio undermined the enemy's sense of security by threatening the sanctity of its city walls and other forms of divine protection. In practice, evocatio was a way to minimize otherwise sacrilegious looting of religious images from shrines.

There are three main recorded examples of evocations, namely this specific transference of Juno Regina, (who was originally the Etruscan goddess Uni) from Veii in 396. One hundred and fifty years later, in 146, a similar evocation was

${ }^{18}$ Cornell, T. J.: The Beginnings of Rome: Italy and Rome from the Bronze Age to the Punic Wars (c. 1000-264 BC). London - New York 1995, 309-313. For the story of the slaughter of the Fabii, who had encamped in the territory of Veii, see Livy 2. 42-50. After constant warfare, the last war (the fourteenth, according to the annalists) broke out in $406 \mathrm{BCE}$. The Romans laid siege to the city, and, after a ten years' siege, M. Furius Camillus took it by storm in 396 BCE, by means, so we are told, of a tunnel leading into the citadel. See Von Vocano, O.-W.: The Etruscans in the Ancient World. Trans. S. A. Ogilvie. Bloomington 1960, 137-149, where he discusses disputes between Veii and Rome; on p. 31 Von Vocano mentions the 5th c. statuette (now at the Villa Giulia) found at Veii, of Aeneas carrying his father out of Troy. Re: Tolumnius, king of the Veii; see Livy 4. 17-19, 32, 58.

${ }^{19}$ Livy 2. 47-48.

${ }^{20}$ CORNELl (n. 18) 312. 
performed by Scipio Aemilianus at Carthage itself. ${ }^{21}$ The ritual was performed in 146, at the end of the Second Punic War; after the Romans defeated the Carthaginians (the very thing Juno fears in Aeneid One!), the Carthaginian goddess Tanit, also known as Juno Caelestis who is often identified with Etruscan Uni/Juno Regina of Veii, was thus similarly summoned from the city. M.-L. Hänninen points out that even during the Second Punic War ceremonies meant to placate Juno Regina of the Aventine were carried out three times - in 218, 217 and 207 - by groups of matrons, suggesting the Roman recognition that, because of her identification with Carthaginian Tanit of Carthage, she was a particularly important goddess to keep on their side during the Punic wars. $^{22}$

If we then link Juno's anxieties at the beginning of the Aeneid over the fated fall of Carthage (which was destined to happen in the Punic Wars) with the Veientine wars - and these wars were two of the three Roman conflicts which ended with the evocation of Juno - the saevae memorem Iunonis ob iram, we find that her "cruel, unforgetting anger" acquires a whole new meaning, which has not only a mythical but also an historical basis. The details of the fall of Veii are, as we have indicated, strongly colored by traditions. In addition to the comparison of the Veientine war to the ten-year war at Troy, numerous details of this actual war are colored by religiosity and mysticism, so we should not be surprised if it influenced Vergil's depiction of the struggle between the Trojans and the Etruscans in the second half of the book. According to Livy, the end of Veii was predicted in "Books of Fate" (Livy 5. 14. 4; 5. 15. 11) as a result of a religious offence committed by its king (Livy 5. 1. 4-5), ${ }^{23}$ and, as I have said, the war ends with the final evocatio of Juno Regina, the goddess of Veii, who was persuaded to abandon the city and go over to Rome. Camillus, Livy says, left his headquarters and took the auspices. Livy has him say:

${ }^{21}$ The third occasion occurred in the capture of a Cilician town, Isaura Vetus, in 75 BCE. According to Plutarch (Ant. 75), a similar evocatio of Dionysus from Alexandria was practiced by the forces of Augustus after its fall in $30 \mathrm{BCE}$. "The fall of Alexandria would be the greatest conquest of an enemy city since Carthage itself, and Cleopatra was the greatest threat to Rome since Hannibal. Octavian was the man who had solemnly recalled the old fetial formula for declaring war, he would hardly neglect an opportunity like this, and evocatio is exactly what we should expect. Antony had played Dionysus-Osiris for long enough. Now he indeed is to be deserted by his god." Pelling, C.: The Augustan Period 43 B.C.-A.D. 69 [The Cambridge Ancient History. Eds. A. K. BOWMAN - E. CHAMPlin - A. LinTOTT. Vol. X.]. Cambridge 1996, 63.

${ }^{22}$ M.-L. HÄNNINEN (Juno Regina and the Roman Matrons. In SETÄLÄ. P. - SAVUNEN, L. [eds.]: Female Networks and the Public Sphere in Roman Society. Acta Instituti Romani Finlandiae 22 [1999] 39-52. Rev. E. A. HEMELRIJK, University of Leiden in BMCR 2000. 03. 11) has focused on ceremonies which were meant to placate Juno Regina of the Aventine during the second Punic War, in which, she argues, Roman matrons had a special role. Three times during this war (in 218, 217 and 207 BCE) groups of matrons approached Juno Regina trying to appease her by a gift for which, at least in one case, they had organized a collection among themselves. In order to explain why women played such an important role in expiating Juno Regina of the Aventine in times of war, Hänninen argues that the origin of this goddess as a tutelary deity of the Etruscan city of Veii, once the enemy of Rome, and her possible identification with the goddess Tanit of Carthage made her a particularly important goddess to keep on one's side during the Punic wars.

${ }^{23}$ Cf. Cornell (n. 18) 312. 
"Pythian Apollo, ... led by you and inspired by your holy breath, I go forward to the destruction of Veii, and I vow to you a tenth part of the spoils. Queen Juno, to you too I pray, that you may leave this town where now you dwell and follow our victorious arms into our City of Rome, your future home, which will receive you in a temple worthy of your greatness.",24

Camillus' men, who had dug a tunnel under the walls of Veii into the temple of Juno on the city's citadel, then burst out of the temple into the city, attacking the Veientine forces who were manning their walls from behind. (Livy 5. 21-22).

Juno Regina had two temples (aedes) in Rome. The one dedicated by Furius Camillus in 392 BCE stood on the Aventine Hill. Here was housed the wooden statue of the Juno which had been transported from Veii. It is mentioned several times by Livy in connection with sacrifices offered in atonement of omens. It was later restored by Augustus, ${ }^{25}$ who made Veii a municipium in 2 BCE, granting them the privileges of Roman citizens (curiously, this was long after these privileges had been granted to other Latin communities, following the Social War of 90-89 BCE). Cornell suggests ${ }^{26}$ that Rome did grant citizenship to the population of Veii after the Gauls sacked Rome in 390 - six years after its fall - in order to block any rebellion while Rome was in a weakened condition after the Gallic invasion of the city. The approximate site of the temple in Rome on the Aventine is indicated by two inscriptions found near the church of S. Sabina. The date of the dedication and of her festival was September 1.

Juno's role as goddess of Carthage is reflected in detail in Aeneid I 446-493, in the temple Dido built for her there, and also in Juno's hope that one day Carthage would rule the world - "This would be her people's kingdom, if somehow fate would allow it" hoc regnum dea gentibus esse, / si qua fata sinant, iam tum tenditque fovitque (Aen. I 15-16). Hera/Juno frequently appears as a resident goddess, not only in Greek states but also in Magna Graecia - that portion of Southern Italy from Campania to Messina and in Sicily - where the Greeks established early settlements. Her main temples in Greece were at Argos, Samos, and Corinth. The temple at Argos, where the marriage of Hera and Zeus was celebrated every year, had a long history of being destroyed and reconstructed all the way to Roman times, when it was plundered by Antony in $39 \mathrm{BC}$ - it may be significant to this reading of Vergil that Augustus later restored many of this temple's works of art.

In Magna Graecia there are a number of temples to Hera. The first one the Trojans encounter, in Aen. III 530, appears just after their first sight of Italy in Calabria, where they stop briefly and make offerings to Juno, as Helenus had advised them,

${ }^{24}$ Livy 5. 21: Tum dictator auspicato egressus cum edixisset ut arma milites caperent, "tuo ductu”" inquit, "Pythice Apollo, tuoque numine instinctus pergo ad delendam urbem Veios, tibique hinc decimam partem praedae uоиеo. Te simul, Iuno regina, quae nunc Veios colis, precor, ut nos uictores in nostram tuamque mox futuram urbem sequare, ubi te dignum amplitudine tua templum accipiat”.

${ }^{25}$ Augustus, Res Gestae 19. 2: aedes in Capitolio Iovis Feretri Iovis Tonantis, aedem Quirini, aedes Minervae et Iunonis Reginae et Iovis Libertatis in Aventino. "I built ... the temples on the Capitol of Jupiter Feretrius and Jupiter the Thunderer, the temple of Quirinus, the temples of Minerva and Queen Juno and Jupiter Libertas on the Aventine."

${ }^{26}$ See CORNELL (n. 18) 320. 
and then sail around "Herculanean Tarentum", the site where Hercules (whose ties to Juno are certainly relevant to this topic), had been attacked by Lacinius, a local robber, while returning from Erythia with Geryon's cattle. After Hercules had killed Lacinius, he dedicated there, on that promontory, a temple to diva Lacinia, "the Lacinian Goddess", which Aeneas and the Trojans observe as they pass (Aen. III 553).

There are other temples of Hera/Juno, often placed along the coast, as if to protect the land on which they are situated. At Paestum there are two enormous temples of Hera, built around 460-450 BCE, which still stand, along with a third, older one, of Athena. They are very near to the coastline (in World War II American troops landed there at night and the next morning were amazed to find themselves in the midst of these still-magnificent temples).

Another important temple is at Selinus (now Selinunte), on the southern coast of Sicily, which is mentioned in Aen. III 705 (palmosa Selinus). An important oracular site for Hera, not widely recognized as such, was originally at Cumae, although it was rededicated to Apollo, possibly in 410 BCE. Here, as at Delphi, it appears that Apollo usurped the resident deity's oracular site, already occupied by a powerful female deity. (As H. W. Parke has demonstrated, Sibyls tend not to be associated with Apollo.) I and others have elsewhere elaborated the question of the Sibyl's ties at Cumae to Hera rather than Apollo, following the work of Margherita Guarducci, ${ }^{27}$ including the bronze disc with Hera's name, which was actually discovered in its vicinity. On the disc is written (in archaic Greek), "Hera does not permit a supplementary inquiry of the oracle" hére ouk eai epimanteuesthai ${ }^{28}$ - in other words, you cannot ask the oracle for more information than she gave you in her original response - this fragment provides a significant piece of evidence as to which god originally held sway there.

There were many early Roman forms of Juno which were not necessarily merged with Hera. These include Juno Sospita, to whom a temple was said to have stood on the Palatine, but who was originally a goddess of Lanuvium, another ancient city about twenty miles south of Rome; Lanuvium had warred against Rome until it was conquered in $338 \mathrm{BCE}$.

Anchises' review in Aeneid 6 of future Roman history begins with Silvius Aeneas, the first king, and ends with the Second Punic War, with three non-chronological insertions, of Augustus, of Caesar and Pompey, and of the Gracchi. The conspicuous insertion of Augustus (VI 791-807) after Romulus, the first king, and before Numa, the second king after Romulus is but one indication of Vergil's elevation of Augustus. Romulus (VI 777-778), the first king after Silvius Aeneas (VI 760-770), waged Rome's first major war against an organized state, namely, Fidenae in 437-

\footnotetext{
${ }^{27}$ JOHnStOn: Juno's Anger (n. 3) 13-23. Cf. PARKE, H. W.: Sibyls and the Sibyline Prophecy in Classical Antiquity. London - New York 1988, 71-72.

${ }^{28}$ First published by GUARDUCCI, M.: Un antichissimo responso dell'oracolo di Cuma. BCAC 72 (1946-48) 129-141, here 129. For more detail, see JOHNSTON: Juno's Anger (n. 3) 16-17 and note 8.
} 
$426 \mathrm{BCE}$, as I discussed above. ${ }^{29}$ Augustus is then named, completely out of chronological order, immediately after Romulus (VI 789-807), with all his accomplishments including the defeat of Antony and of Egypt. His wide-spread conquests are then compared to those of Hercules (VI 801-803) and Liber (VI 804-805).

The list of early kings then continues, beginning with Numa Pompilius (VI 808812), whose representation suggests that of Augustus on the Ara Pacis (which was not commissioned until 13 BCE, six years after Vergil's death). Numa is represented as a venerable priest "offering sacrifice" and "decked with boughs of olive", the symbol of peace, who will be the "first to found a city based on laws" (VI 808-812).

Brutus's defeat (VI $827 \mathrm{ff}$.) of the Tarquinii marks the beginning of the Roman Republic. By transferring the epithet 'superbam' to Brutus, Vergil suggests an ambivalence between admiration and criticism of the man who overthrew the tyrant but who also had his own sons executed (natosque pater nova bella moventis / ad poenam pulchra pro libertate vocabit, VI 820-821), with his love for his country overcoming his love for his children (VI 823). Vergil's detail about Brutus causing the death of his sons could well be colored by the possible association with the later Brutus, to whom Julius Caesar is said to have uttered, in dying, "even you, my son?" kai su, teknon? $?^{30}$

The events that follow (Aspice Torquatum et referentem signa Camillum, VI $825)$ both occurred in 361 BCE: Titus Manlius Imperiosus "Torquatus", after winning a single combat against a Gaul of enormous size and strength, acquired his agnomen when he stripped the necklace from the corpse of his opponent. Vergil associates Furius Camillus with that same year, when he "returned the standards". In this year (361 BCE) he recovered the gold paid to the Gauls so they would retreat from Rome. Vergil changes the gold, however, to the Roman standards (signa), perhaps reflecting the recovery - or the anticipation of the recovery - of the standards from the Parthians, (which was achieved in by Augustus, in $20 \mathrm{BCE}$ ). ${ }^{31}$ Note that there is no reference in Anchises' survey to Camillus' destruction of Veii in 396 BCE, but on Aeneas' shield in book eight, offerings by Roman matrons after Camillus' destruction of Veii in that year are depicted:

castae ducebant sacra per urbem
pilentis matres in mollibus

${ }^{29}$ The title of Romulus, however, according to Werner Eck, was associated too strongly with notions of monarchy and kingship, an image Octavian tried to avoid. ECK, W.: The Age of Augustus. Trans. D. L. SCHNEIDER, new material by S. A. TAKÁCS. Oxford 2003, 149.

${ }^{30}$ And who apparently may or may not have been descended from his namesake.

${ }^{31}$ See Augustus, Res Gestae 1. 29: Signa militaria complura per alios duces amissa devictis hostibus recepi ex Hispania et Gallia et a Dalmateis. Parthos trium exercitum Romanorum spolia et signa reddere mihi supplicesque amicitiam populi Romani petere coegi. Ea autem signa in penetrali quod est in templo Martis Ultoris reposui. "I recovered many military standards which had been lost by other generals, after conquering the enemies, from Spain and Gaul and Dalmatia. I compelled the Parthians to return to me the spoils and standards of three Roman armies and to seek submissively the friendship of the Roman People. I placed those standards in the sanctuary in the temple of Mars Ultor." See also Hor. Od. 1. 2. 51 and 1. 12. 53 . 
chaste mothers in cushioned carriages were bringing their offerings through the city

The next section of Anchises' prophecy (VI 826-835) is the second non-chronological insertion, much like the insertion of Augustus into the sequence of the kings of Rome. Here Anchises foretells the disaster of civil war, specifically between Caesar and Pompey (48 BCE) (this is surely also meant also to imply the civil war that has just ended between Augustus and Antony).

The fourth section begins with Lucius "Achaicus" Mummius' victory at the Battle of Corinth in 146 BCE. This is also the date of the end of the Third Punic War, which may be relevant to what follows in Anchises' prophecy, since all the names except for Cossus and the insertion of the Gracchi have to do with one of the Punic Wars (as does the reference above in VI 825 to Marcus Livius Drusus). We hear first of the victory of Aemilius Paulus, father of Scipio Aemilianus Africanus (Minor) in 168 BCE at Pydna (over Perseus); then we come to M. Porcius Cato "the Censor", vociferous opponent of the Carthaginians, and Cornelius Cossus, who slew Lars Tolumnius, king of Veii in 428 BCE.

The Gracchi are the third non-chronological intervention, VII 826-835. The deaths of Tiberius Gracchus (d. 133 BCE) and of Gaius Gracchus (d. 123 BCE) marked the beginning of the Roman Revolution and the fall of the Republic a century later.

The narrative returns (VI $836 \mathrm{ff}$.) to the Scipios and their victories at Carthage (Africanus Maior at Zama in 202 and Africanus Minor at Carthage in 146 BCE), and then moves backward, to Fabricius, who fought against Pyrrhus in 282 and 278 BCE, and then to Serranus (cos. 257), who defeated the Carthaginians just off the Liparean Islands (Sicily). Finally it moves to the beginning of the second Punic War, characterized by Quintus Fabius Maximus "delaying" (cunctando) Hannibal in 217 BCE. The whole prophecy concludes with Anchises' call for a Pax Romana, and the moving description of Marcellus.

\section{CONCLUSION}

The Aeneid is many things: It is a grand epic of the roots of Rome, from its Trojan founders, who are seen as the ancestors of Romulus, through the struggles of the nation as it grew, first by overcoming, and then by incorporating its opponents into one nation. Anchises' review of future Romans in book six to some extent encapsulates the ideal of reconciliation between opposing forces, and no doubt is a reflection of Augustus' vision of what he wants to accomplish as ruler. Vergil clearly had a similar view, and as a result made this a central theme in his epic.

One of the great challenges to Augustus is to overcome the broad opposition to a new ruler, including all those opponents and obstacles that Augustus had to overcome to achieve his new golden age. This opposition is symbolized in the Aeneid by Juno, who was an important deity in Italy before the coming of the Trojans. Juno clearly was a powerful goddess. Her opposition to the Romans, as we have seen, 
clearly has its origin not only in Greek mythology, but from a Roman point of view, in history itself as the protector of the lands the Trojans seek to invade. Consider the times in the poem when Juno becomes most antagonistic to the Romans: On the first occasion, at the beginning of Book One, the Trojans are about to set sail for Italy. True, they have briefly set foot on the eastern side of Italy, and their presence in Sicily apparently does not disturb this goddess. But when they are heading for the mainland of Italy - that is when she attacks. She clearly wants to prevent their arrival in Italy proper. One way she tries to stop them is by casting them ashore in Carthage and encouraging Aeneas' love affair with Dido, in the hope of keeping the Trojans there and thereby preventing the rise of the state that would one day destroy Carthage.

Once the Trojans finally do arrive on the mainland, she sets in motion a long war. But the one depicted in the Aeneid was not as long as the real wars Romans waged with the Latin League and with many of the tribes of Italy, including the Veii. The tendency in antiquity to associate the Roman war against the Veii with the Trojan War would be consistent with Vergil's wanting to draw such a parallel. Vergil of course includes many tribes of Italy in his epic, not only those Etruscans that opposed the Trojans. Juno's humble acceptance of the Roman victory near the close of Book 12 is remarkably consistent with the reported "willing" acceptance by the goddess in 396 BC of her evocation - as Etruscan Uni - from Veii to Rome. Juno's cult statue, according to Livy, was transported from Veii to Rome, "with miraculous ease".32 The ease of the transportation was interpreted as meaning that Juno was readily persuaded to switch to the Roman side. Near the end of Aeneid 12, Juno, with similar "ease" says to Jupiter, "and now I yield, and I leave the battle, loathing it" et nunc cedo equidem pugnasque exosa relinquo (XII 818). And then she makes her final request, that, in effect, the Trojan race become assimilated with the Latin peoples and adopt the Latin language and mode of dress. Historically, the tribes conquered by the Romans and the Trojans were assimilated into the Roman race, and those cities that were not destroyed (unlike Veii - although it did survive to some degree) were colonized and eventually became Roman. Juno's conversion in Book XII - from hostility against to support for - the new Roman race, thus reflects the unification of disparate forces that Augustus is attempting to accomplish in Italy, and ultimately, in the wider world.

\author{
Patricia Johnston \\ Department of Classical Studies \\ Brandeis University \\ 415 South St. \\ Waltham, MA 02453
}

${ }^{32}$ Livy 5. 22. 3-6; see CORNELL (n. 18) 312. 